\title{
Respiratory health of elite athletes - preventing airway injury: a critical review
}

\author{
Pascale Kippelen, ${ }^{1}$ Kenneth D Fitch, ${ }^{2}$ Sandra Doreen Anderson, ${ }^{3}$ Valerie Bougault, ${ }^{4}$ \\ Louis-Philippe Boulet, ${ }^{5}$ Kenneth William Rundell, ${ }^{6}$ Malcolm Sue-Chu, ${ }^{7,8}$ \\ Donald C McKenzie ${ }^{9}$
}

${ }^{1}$ Centre for Sports Medicine \& Human Performance, Brunel University, Uxbridge, UK ${ }^{2}$ School of Sports Science, Exercise and Health, Faculty of Life Sciences, University of Western Australia, Crawley, Western Australia, Australia ${ }^{3}$ Respiratory and Sleep Medicine, Royal Prince Alfred Hospital, Camperdown, New South Wales, Australia ${ }^{4}$ Faculté des Sciences du Sport, Université Droit et Santé de Lille 2, Lille, France ${ }^{5}$ Centre de recherche de I'Institut universitaire de cardiologie et de pneumologie de Québec, Quebec, Canada ${ }^{6}$ Medical Affairs, Pharmaxis, Exton, Pennsylvania, USA 7Department of Thoracic Medicine, St Olavs Hospital, University Hospital of Trondheim, Trondheim, Norway

${ }^{8}$ Department of Circulation and Imaging, Norwegian University of Science and Technology,

Trondheim, Norway

${ }^{9}$ Division of Sports Medicine,

School of Human Kinetics,

University of British Columbia,

Vancouver, Canada

\section{Correspondence to}

Pascale Kippelen, Brunel University, Centre for Sports Medicine \& Human Performance, Uxbridge UB8 3PH, UK;

pascale.kippelen@brunel.ac.uk

Received 9 February 2011 Accepted 6 March 2012 Published Online First 20 April 2012

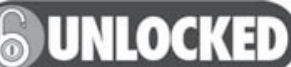

This paper is freely available online under the BMJ Journals unlocked scheme, see http:// bjsm.bmj.com/info/unlocked.dtl

\section{ABSTRACT}

Elite athletes, particularly those engaged in endurance sports and those exposed chronically to airborne pollutants/irritants or allergens, are at increased risk for upper and lower airway dysfunction. Airway epithelial injury may be caused by dehydration and physical stress applied to the airways during severe exercise hyperpnoea and/or by inhalation of noxious agents. This is thought to initiate an inflammatory cascade/repair process that, ultimately, could lead to airway hyperresponsiveness (AHR) and asthma in susceptible athletes. The authors review the evidence relating to prevention or reduction of the risk of AHR/ asthma development. Appropriate measures should be implemented when athletes exercise strenuously in an attempt to attenuate the dehydration stress and reduce the exposure to noxious airborne agents. Environmental interventions are the most important. Nonpharmacological strategies can assist, but currently, pharmacological measures have not been demonstrated to be effective. Whether early prevention of airway injury in elite athletes can prevent or reduce progression to $\mathrm{AHR} /$ asthma remains to be established.

\section{INTRODUCTION}

This paper follows on from the May 2012 edition of BJSM in which our group published a series of papers on the respiratory health of the elite athlete. ${ }^{1-9}$ The key points made by the authors in the previous issue were as follows: first, airway hyperresponsiveness (AHR)/asthma is the most common chronic medical condition experienced by both Summer and Winter Olympic athletes; ${ }^{8}$ second, those athletes sustaining high ventilation during exercise and/or those exposed to environmentally unfavourable conditions (such as cold dry air, polluted air or chlorinated indoor pools), ${ }^{5-7}$ are likely to incur injury to the airway epithelium during high-level exercise; third, in susceptible athletes, the repeated injury and repair process of the epithelium could lead to structural and functional changes within the airways and be the underlying cause for the development of AHR/asthma. ${ }^{3}$

This paper prepared by the same authors briefly presents the main respiratory conditions observed in elite athletes and indicates their likely origin. The second part focuses on the preventive strategies that can, or might be implemented by or for elite athletes to reduce the risk of airway injury. Experimental work supports the need for improved control of the environment in which athletes train and compete in order to limit injury derived from exposure to cold dry air and to noxious agents. As yet, it is not known if the pharmacological agents used in treating asthma and exercise-induced bronchoconstriction (EIB) are effective in preventing airway injury in athletes.

\section{PREVALENCE AND ORIGIN OF AIRWAY DYSFUNCTION IN ATHLETES Lower airway dysfunction \\ AHR and asthma}

AHR, as defined by a positive bronchial provocation test to a physical stimulus (ie, exercise, dry air hyperpnoea or hyperosmolar aerosols) or to a pharmacological stimulus (ie, inhaled methacholine or histamine), and asthma are the most common chronic medical conditions in Olympic athletes, with a prevalence of 7 to $8 \%$. However, large variations in prevalence exist between sports. ${ }^{8}$ It is clear that sports that involve strenuous endurance training requiring athletes to inspire large volumes of air, increase the risk of developing AHR/ asthma. For example, Olympic Nordic combined and cross-country skiers, who sustain high levels of ventilation (up to $200 \mathrm{l} / \mathrm{min}$ ) for prolonged periods and who compete often in very low ambient temperatures have a prevalence of asthma/AHR of $\sim 15 \%{ }^{8}$ This is in contrast to a prevalence of less than $4 \%$ in their counterparts who alpine ski and ski jump, yet train in similar weather conditions but do not inhale large quantities of cold dry air. In addition, those athletes exposed to airborne irritants, pollutants or allergens while exercising are at increased risk for AHR/asthma. Over $17 \%$ of Olympic swimmers and $13 \%$ of synchronised swimmers have AHR/asthma. ${ }^{8}$ Breathing air containing chloramines (ie, byproducts of chlorination) during the many hours of training in indoor pools appears to be the reason for the high prevalence of AHR/asthma in swimming sports. The finding that AHR was attenuated or even disappeared when swimmers stopped high-level training ${ }^{10} 11$ suggests that, for some subjects at least, the AHR is 'exercise induced'. In contrast, in diving, a skill sport without an endurance training component but conducted mostly in indoor chlorinated pools, few athletes $(\sim 4 \%)$ have AHR/asthma. (IOC Independent Asthma Panel, 2002-2011)

Athletes training and competing in indoor skating rinks breathe relatively cold air and may be exposed to particulate matter (PM) and nitrogen oxides $\left(\mathrm{NO}_{\mathrm{X}}\right)$ from ice resurfacing machines powered by fossil fuels. Olympic speed skating, which 
is an endurance sport conducted in a larger indoor skating venue, counts $\sim 12 \%$ of athletes with AHR/asthma. ${ }^{8}$ Ice hockey players and figure skaters breathe similar air, but neither group can be considered as endurance trained. Nevertheless, their risk to develop AHR/asthma seems also increased, ${ }^{12}$ in part because of the poor air quality in indoor ice arenas. ${ }^{13}$ Olympic cyclists, who spend many hours training on the road and, who are often exposed to $\mathrm{PM}, \mathrm{NO}_{\mathrm{X}}$ and ozone $\left(\mathrm{O}_{3}\right)$ have a high prevalence of AHR/asthma $(\sim 17 \%){ }^{8}$ Unsurprisingly, Olympic triathletes who encounter the respiratory environments and the training schedules of both swimmers and cyclists have the highest percentage $(-25 \%)$ of AHR/asthma. ${ }^{8}$

These observations on prevalence are consistent with the concept that the ventilatory demands of the sport and the training environment are two major determinants in the development of AHR/asthma in elite athletes.

From a mechanistic point of view, breathing at high flow for prolonged periods causes significant dehydration and cooling of the airway mucosa. This dehydration is associated with release of inflammatory mediators that ultimately cause airway narrowing in those athletes with asthma. ${ }^{14}$ However, it is important to acknowledge that all athletes, whether they have asthma or not, may incur airway epithelial injury. During high-level exercise, severe hyperpnoea exposes the airway epithelium to increased shear stress and transmural pressure gradients. Those increased physical forces may then place the dehydrated epithelial cells at risk of sloughing or even complete detachment. ${ }^{3}$ Moreover, the repeated stretch and the compression of airway epithelial cells at high flow rates may negatively impact on the functioning of the epithelial cells. ${ }^{3}$ Although airway epithelium has the capacity to repair itself quickly, the repeated injury-repair process is thought to be responsible for structural and functional changes. Evidence for structural changes (airway remodelling) comes from bronchoscopy of elite swimmers ${ }^{15}$ and cross-country skiers. ${ }^{16}$ Moreover, the late development of AHR documented so often in elite athletes ${ }^{8}$ is in keeping with a relatively slow but progressive process, whereby over time, injury-induced plasma exudation modifies the contractile properties of the bronchial smooth muscle. ${ }^{17}$

In this context, it is easy to understand why inhalation of cold air or of noxious agents such as by-products of chlorination or airborne pollutants poses an extra challenge to the airways. Cold air is always dry. Therefore, inhalation of cold air increases the dehydration stress to the airways. ${ }^{14}$ Moreover, the airway cooling during exercise followed by rapid re-warming of the airways after exercise could add an additional stress (ie, a thermal stress). ${ }^{18}$ Numerous crosscountry skiers have AHR only to bronchial challenge with methacholine. ${ }^{1619}$ This may in part be due to enhanced access to the $\mathrm{M}_{3}$ muscarinic receptors on bronchial smooth muscle, and in part to increased contractility of the muscle following injury and repair of the epithelial barrier. Noxious agents can directly interfere with the epithelial cells. In swimmers, the increased numbers of loose epithelial cells in baseline induced sputum samples ${ }^{20}$ is consistent with chloramines-induced injury to the epithelial cells.

\section{Subclinical pulmonary oedema}

Exercise-induced arterial hypoxaemia (EIAH) is a common occurrence in highly trained endurance athletes, with reports estimating that about half the young male ${ }^{21}$ and even a greater proportion of young female athletes 2223 develop various degrees of gas exchange disturbance during high-level exercise. EIAH results in an inadequate supply of oxygen to the working muscles and can limit performance. ${ }^{24}$ The causes are multifactorial. ${ }^{25}$ One possible mechanism is the development of high pulmonary pressures, which may injure the alveolarcapillary membrane resulting in altered gas exchange secondary to transient interstitial oedema. There are reports of haemoptysis, representing lung haemorrhage in highly trained athletes after intense physical activity at sea level. ${ }^{2}$ At high altitudes, non-uniform hypoxic pulmonary vasoconstriction is likely to increase the risk of development of subclinical pulmonary oedema in exercising athletes. ${ }^{26}$

\section{Upper airway dysfunction}

Laryngeal dysfunction

Exercise-induced laryngeal obstruction encompasses conditions such as exercise-induced paradoxical arytenoid motion, exercise-induced laryngomalacia and vocal cord dysfunction (VCD). In elite athletes, VCD appears to be the principal cause for laryngeal obstruction during exercise, with a reported prevalence of $\sim 5 \%$. $^{27}$ The large majority of cases of VCD (>80\%) are found in female athletes ${ }^{27}$ and are often misclassified as asthma. ${ }^{27}$ While in athletes an overlap exists between exerciseinduced laryngeal obstruction and EIB, it is important that both are objectively diagnosed before treatment is implemented. ${ }^{27}$ VCD is associated with the sudden paradoxical narrowing of the glottis which results in the immediate onset of dyspnoea and inspiratory stridor and can lead to hypoxaemia and poor performance. The precise aetiology of VCD is unknown; however, laryngeal hyperresponsiveness, laryngeal irritants and psychogenic factors are regarded as the main causes of this dysfunction. ${ }^{28}$ Gastro-oesophageal reflux disease (GORD) is a common trigger to VCD. ${ }^{29}$ GORD can be diagnosed accurately and precise measurements for acid and non-acid reflux can be made, and proton pump inhibitors will improve VCD. ${ }^{28}$

\section{Cough}

Cough is extremely common in athletes who exercise strenuously, especially in those who participate in winter sports. ${ }^{9}$ In cross-country skiers, the prevalence of respiratory symptoms can be as high as $86 \%$, with cough being the most commonly reported symptom. ${ }^{30}$ While cough is often associated with EIB, more than half the athletes with no evidence of EIB report cough on exertion. ${ }^{31}$ Alongside asthma, any of the following factors might trigger cough during or after exercise in athletes: upper airway cough syndrome related to rhinitis, sinusitis, laryngitis or other upper airways conditions, GORD or exposure to sensitisers/respiratory irritants. ${ }^{32}$

\section{Rhinitis}

Rhinitis is a very common condition in athletes with a prevalence $>30 \% .{ }^{93}$ In swimmers, this value could be as high as $74 \% .{ }^{34}$ Most athletes will have an allergic component to their rhinitis and their condition will worsen under specific environmental conditions; exposure to aeroallergens, inhalation of irritants $\left(\mathrm{O}_{3}, \mathrm{PM}\right.$ and by-products of chlorination) or exposure to cold dry air. In non-atopic athletes, intense training in unfavourable environments (such as chlorinated swimming pools) can also lead to an increase in nasal symptoms. ${ }^{34}$ The occurrence of symptoms may reduce an athlete's ability to train and compete.

\section{Upper respiratory tract infections (URTI)}

Symptoms suggestive of URTI are responsible for 30 to $40 \%$ of visits to sports medicine clinics by elite athletes. ${ }^{9}$ Intense endurance training has been noted to be associated with an 
impaired immune system. ${ }^{35}$ This may explain why URTI are so commonly experienced by elite endurance athletes, particularly around the time of competition. ${ }^{36}$ However, only $~ 30 \%$ of symptomatic upper respiratory illnesses in elite athletes are due to infection and other causes for the illness are yet to be identified. $^{36}$

\section{STRATEGIES TO REDUCE THE IMPACT OF ENVIRONMENTAL FACTORS ON AIRWAY INJURY}

Since injury to the airway epithelium, particularly to the small airways, is thought to initiate the cascade of events that ultimately leads to airway dysfunction in susceptible athletes, ${ }^{3}$ prevention strategies should aim at reducing airway injury. Although there is limited scope to modify the physical forces applied to the airway epithelium during high-level exercise (and hence, to reduce airway injury derived from mechanical stress), various strategies can be implemented to try to attenuate injury caused by dehydration stress and/or noxious agents.

\section{Cold air}

Exercising vigorously in a cold environment will augment injury to the airway epithelium because of both, the increased need to heat and humidify the inspired air, and the potential to increase the area of the airway surface becoming dehydrated. ${ }^{37}$ To prevent dehydration-induced airway injury, cold-weather athletes should employ strategies that increase temperature and water content of the inhaled air.

In the laboratory, an increase in temperature and water content from $4^{\circ} \mathrm{C}, 37 \%$ relative humidity $(\mathrm{RH})$ to $25^{\circ} \mathrm{C}, 94 \%$ $\mathrm{RH}$ has been shown to limit disruption of the airway epithelium induced by high-level exercise. ${ }^{38}$ In the field, increasing the water content of the air inspired can be achieved, either naturally (ie, by raising absolute humidity/water content), through nasal breathing, ${ }^{39}$ or by the use of heat and moisture exchange (HME) devices either used as a mouth piece or as a mask. Theoretically, even a small increase in absolute humidity will reduce the rate of water loss from the airways and reduce potential for airway injury. During exercise, nasal breathing is impractical as breathing switches from nasal to oronasal when ventilation exceeds $\sim 351 / \mathrm{min} .{ }^{40}$ Consequently, the contribution of nasal breathing into the conditioning of inhaled air is negligible during high-level exercise. The only individual strategy left to cold-weather athletes to protect their airways is through the use of HME devices. A number of devices to warm the inspired cold air have been developed and vary from simple face masks ${ }^{41-43}$ to heat-exchange devices. ${ }^{44} 45$ Heat- and moisture-exchange devices recycle heat energy and moisture in the expired air to warm and humidify the inspired air. They can increase the inspired air temperature from minus $10^{\circ} \mathrm{C}$ to at least $19^{\circ} \mathrm{C}^{46}$ and thus diminish airway dehydration and heat and water loss. They have been shown to provide a considerable protective effect against EIB. ${ }^{47}$ Heat and moisture exchange devices should always be used during training at low and subfreezing ambient temperatures, but 'the increased airways resistance and increased dead space makes it difficult to train intensively for long periods, and limits their use during competition'. ${ }^{4}$

Athletes have limited control of the environment in which they train and compete. Nonetheless, sporting federations can play a key role by setting up appropriate thresholds. The Federation Internationale de Ski's (FIS) website has a medical advisor's recommendations of the lower limits of ambient temperature for competition that relate to cross-country skiing only. These are minus $16^{\circ} \mathrm{C}$ for races $30 \mathrm{~km}$ and longer, minus $18^{\circ} \mathrm{C}$ for shorter distance races and minus $20^{\circ} \mathrm{C}$ for sprint races. Information as to the marked effects of a wind chill factor are noted. ${ }^{48}$ However, the actual FIS rules differ somewhat, in that a forecast for the temperature to fall below minus $20^{\circ} \mathrm{C}$ is supposed to lead to a delay or cancellation of the race. ${ }^{49}$ Biathlon has similar rules; competitions must not start if the air temperature is below minus $20^{\circ} \mathrm{C}$. If the temperature is below minus $15^{\circ} \mathrm{C}$, the wind chill factor and humidity must be considered. This could result in a decision not to start if the wind is $10 \mathrm{~km} / \mathrm{h}$ or greater at minus $15^{\circ} \mathrm{C} .{ }^{50}$ In both sports, these rules are to protect athletes against extreme cold, not to reduce airway injury. If implemented, the recommendations of FIS's medical advisor would assist in reducing airway injury in competitive cold-weather athletes.

\section{By-products of chlorination}

The reaction of chlorine-containing agents with organic nitrogen-containing compounds (eg, dirt, sweat, urine) brought into the pool water by users leads to the formation of various by-products, notably chloramines. Some of these are transferred to the atmosphere of swimming pools, either as gases or as droplets (if the surface of the water is churned up), and inhaled by the swimmers. Nitrogen trichloride $\left(\mathrm{NCl}_{3}\right)$, the common by-product of chlorination, is a well-known irritant ${ }^{51}$ that can cause acute disruption of the airway epithelium. ${ }^{52}$ Experimental data suggest that when $\mathrm{NCl}_{3}$ concentration is maintained below $0.3 \mathrm{mg} / \mathrm{m}^{3}$, no short-term changes in lung function or airway epithelial permeability are observed in swimmers. ${ }^{53}$ It is therefore advisable that appropriate hygienic measures and ventilation systems are in place to maintain $\mathrm{NCl}_{3}$ below this threshold at all times.

Modification of swimmers' behaviour is important and includes the following: showering with soap before entering the pool, wearing a swim cap, using a swimsuit reserved exclusively for swimming, respecting personal hygiene precautions before entering the pool, bare feet zones, and removing makeup and other cosmetics. Elite swimmers and synchronised swimmers should avoid staying in a chlorinated atmosphere when undertaking out-of-water training. Sanitary authorities and swimming pool managers must ensure optimal air quality in pool environments. Adequate ventilation (ie, a flow rate of fresh air of at least $60 \mathrm{~m}^{3} / \mathrm{h}$ ) should be maintained to reduce the concentration of chloramines accumulated in the air above the pool water. Ventilation equipment must be regularly maintained. ${ }^{54}$ Other measures, such as swimmers not crossing between dirty and clean areas, and the provision of a footbath containing an appropriate disinfectant could further assist. Finally, the safety of alternative chemical disinfectants to chlorine (such as ozone, bromide and chlorine dioxide) could be further explored to determine whether they are viable alternatives to chlorine. ${ }^{55}$

\section{Other airborne pollutants}

Air polluted by combustion engines, especially freshly generated PM, is considered highly injurious to the airways. ${ }^{7}$ Dehydrated and damaged airways are believed to be more vulnerable to the deleterious effects of PM, particularly small and ultrafine $\mathrm{PM}\left(\mathrm{PM}_{1}\right)$ which can penetrate deeper into the lungs. ${ }^{56}$ Ozone ${ }^{5758}$ and $\mathrm{NO}_{\mathrm{X}}{ }^{5859}$ are other pollutants that can provoke injury to the airways. High ventilation during strenuous exercise results in greater deposition of PM in the lungs 
and in higher concentrations of $\mathrm{O}_{3}$ and $\mathrm{NO}_{X}$ entering the airways, hence increasing the risk of airway injury. ${ }^{60}$

Meticulous attention to indoor air quality in ice skating arenas, especially with regard to the levels of $\mathrm{NO}_{\mathrm{X}}$ and $\mathrm{PM}_{1}$, is important to minimise airway injury and inflammation in ice hockey players and speed and figure skaters. This can be achieved by increasing the ventilation in these arenas ${ }^{61}$ and by using electric powered rather than fossil-fuel powered ice resurfacing machinery. The latter measure was undertaken by the Organising Committee at the 2010 Vancouver Winter Olympic Games.7 Moreover, at the 2008 Beijing Summer Games, an extensive program to improve air quality was undertaken by the Beijing Environmental Bureau, which included removing old high-polluting vehicles, switching from diesel to gas power buses and mandatory restrictions on use of private vehicles. This resulted in marked improvement in air quality, especially PM at the time of the Games. ${ }^{62}$

Traffic emissions are a major source of pollutants, so that there is potential for problems for athletes using sporting fields in close proximity to major roadways ${ }^{7}$ and for cyclists who can be heavily exposed when riding in the urban environment. It is important to establish a buffer zone from high-traffic routes where individuals may exercise without excessive exposure to pollutants. Exercise should be avoided in areas where PM levels exceed the standards set by Environmental Protection Authorities (EPA). Precautions to reduce the effects of PM inhalation include avoiding exercise near roads when traffic congestion is high and exercising at least $250 \mathrm{~m}$ from major roadways. Athletic venues, parks, and exercise areas near high-traffic roadways should have trees, preferably evergreens, placed between the road and the facility. This approach will increase atmospheric dilution and agglomeration which increases particle size and decreases the particle number, thus reducing the deposition in the lower airways and the potential for airway injury. Athletes should be cognisant of $\mathrm{PM}, \mathrm{O}_{3}$ and $\mathrm{NO}_{X}$ concentrations when exercising outdoors. It would be prudent for cyclists, endurance runners and race walkers to plan to train early in the morning when these pollutants are generally at their diurnal low.

Fumes from fluorinated ski waxes emanating from daily hot waxing can contribute to airway injury in Nordic and alpine skiers. ${ }^{63}$ Hot waxing results in ultrafine fluorine particles being released into the air in concentrations 25 -fold higher than prewaxing. Animal studies have shown that these fluorine particles are quite toxic. ${ }^{64}$ Although this exposure does not occur during exercise, it occurs on a daily basis beginning early in the skier's career. Skiers should be deterred from spending long hours in the waxing room and should make sure the area is always well ventilated.

\section{Miscellaneous measures}

In athletes who are atopic, have rhinitis, or have higher than normal levels of circulating immunoglobulin E ( $\operatorname{IgE})$, repeated injury-repair of the airway epithelium is thought to create a model of 'passive sensitisation' of the bronchial smooth muscle and increase the risk for AHR. ${ }^{17} 65$ Consequently, athletes with known allergies/rhinitis should avoid training in environments where levels of airborne allergens are high.

Respiratory tract infections, including the common cold, are likely to increase the vulnerability of the airway epithelium to injury. Athletes should therefore endeavour to avoid contact with persons showing signs of upper airway infections, particularly while undertaking intensive training schedules and before major competitions. When athletes are members of sporting teams housed together, any team member who is developing a respiratory tract infection should be isolated as far as is practical. When possible, athletes should refrain from intense training or competition for up to a week after an infection. ${ }^{66}$ Athletes with asthma should consider having an annual influenza vaccination.

\section{OTHER STRATEGIES TO REDUCE EXERCISE-INDUCED AIRWAY INJURY IN ELITE ATHLETES Non-pharmacological interventions}

Warm-up exercises ${ }^{67} 68$ and intermittent exercises ${ }^{6970}$ are well known to reduce the severity of EIB. The beneficial effects of these exercises are thought to be mediated by an increase in bronchial blood flow and in the rate of water return to the airway surface. It can therefore be anticipated that warm-up and intermittent exercises would also protect athletes against airway epithelial injury.

\section{Pharmacological interventions}

Limited experimental data are as yet available regarding the use of pharmacological agents to prevent airway injury. While animal studies suggest a potential beneficial effect of inhaled corticosteroids (ICS) to attenuate various aspects of airway remodelling, ${ }^{71} 72$ variable results have been obtained in asthmatic patients. ${ }^{73-75}$ Moreover, the only long-term study carried out on athletes (ie, in cross-country skiers) suggests that daily treatment with ICS does not have any beneficial effect on respiratory symptoms or AHR to methacholine. ${ }^{76}$ Finally, implementing treatment with ICS at inception of asthma in early childhood in those genetically at risk failed to influence the natural history of the disease. ${ }^{77} 78$ Therefore, the prophylactic use of ICS to prevent airway injury in athletes is not recommended.

The leukotriene receptor antagonist montelukast can be used for maintenance treatment of asthma and for prevention of EIB. The benefits of prescribing montekulast to athletes with asthma/AHR are however not universally accepted. ${ }^{79} 80$ Nonetheless, montelukast has been shown to provide greater protection against bronchoconstriction caused by the inhalation of ice rink air containing high concentrations of $\mathrm{PM}_{1} \mathrm{com}$ pared to the same air with lower concentrations of $\mathrm{PM}_{1} \cdot{ }^{81} \mathrm{Th}$ is suggests that bronchoconstriction, and thus airway injury, may be leukotriene mediated. Further studies are needed to confirm the potential for montelukast to attenuate airway epithelial injury in those athletes routinely exposed to airborne pollutants.

Oxidative stress is a key component of pollutant-induced bronchoconstriction. ${ }^{82} 83$ Therefore, antioxidant supplementation has been proposed as complementary therapy for athletes exposed to air pollutants. In amateur cyclists, a mixture of antioxidants conferred partial protection against ozone-mediated adverse effects. ${ }^{84} 85$ Moreover, short-term supplementation with antioxidants (vitamin $\mathrm{C}$ and $\mathrm{E}$ ) has been shown to reduce airway oxidative stress and epithelial disruption induced by high-level exercise in hot, humid and $\mathrm{O}_{3}$-polluted environment in runners. ${ }^{86}$ A protective effect of lycopene, ${ }^{87}$ fish oil supplementation $^{88}$ and undenatured whey protein ${ }^{89}$ has also been demonstrated in subjects with EIB exercising in non-polluted air. However, some of those results were not replicated in a population of young athletes with exercise-related breathing difficulties. ${ }^{90}$ The long-term effects (both beneficial and detrimental) of chronic use of antioxidant supplementation on the 
respiratory health of athletes are unknown at this time. Until further experimental data are obtained, athletes should not be recommended to use antioxidant supplementation to prevent airway injury.

Since atopy has been identified as a risk factor for asthma/ AHR in elite athletes, ${ }^{91}$ strategies aiming to limit allergic airway inflammation could be beneficial to the athletes. Recently, in a murine model of allergic asthma, L-arginine (the precursor of nitric oxide) has been shown to reduce the widening of intercellular spaces between adjacent bronchial epithelia, ${ }^{92}$ as well as AHR, airway inflammation and various aspects of airway remodelling. ${ }^{93}$ Whether dietary L-arginine supplementation could be used in susceptible athletes (ie, those with disordered nitric oxide metabolism) to improve the health of the airway epithelium remains to be established.

In conclusion, there is compelling evidence that elite athletes are at increased risk for airway dysfunction. This risk however varies across sports, depending mainly upon the mechanical and dehydration stresses generated within the airways, and the level of noxious agents (ie, airborne pollutants, irritants or allergens) inhaled by athletes during exercise. Both dehydration stress and exposure to noxious agents are modifiable factors in the development of airway injury. Therefore, prevention strategies, such as the use of HME devices during training in cold environments, the fixing of appropriate thermal thresholds during competitions conducted in subfreezing conditions and the introduction of stricter regulations on air quality in indoor sportive arenas/swimming pools, should be enforced. Moreover, close monitoring of the lung function of elite athletes 'at risk' for AHR/asthma should be implemented. The efficacy of various pharmacological agents in inhibiting acute airway injury should be experimentally validated. Finally, there is an urgent need to conduct longitudinal studies in order to establish whether implementation of prevention strategies for airway injury are effective in reducing the risk for long-term development of airway dysfunction in elite athletes.

Contributors PK and KF drafted the article and, following throughout critical review from SDA, produced the finalised version. SDA, VB, LPB, KWR, MSC and DMK contributed to specific sections of the manuscript and revised it critically for important intellectual content. Final approval of the version to be published was given by all co-authors.

\section{Competing interests None.}

Provenance and peer review Commissioned; internally peer reviewed.

\section{REFERENCES}

1. Fitch KD, Anderson SD. Intense exercise and airway hyper-responsiveness/asthmaimportance of environmental factors. Br J Sports Med 2012;46:379-80.

2. McKenzie DC. Respiratory physiology: adaptations to high-level exercise. Br J Sports Med 2012 Published Online First: 20 January 2012 doi:10.1136/bjsports-2011-090824

3. Kippelen P, Anderson SD. Airway injury during high-level exercise. Br J Sports Med 2012 Published Online First: 12 January 2012 doi:10.1136/bjsports-2011-090819.

4. Anderson SD, Kippelen P. Assessment and prevention of exercise-induced bronchoconstriction. Br J Sports Med 2012 Published Online First: 12 January 2012 doi:10.1136/bjsports-2011-090810.

5. Bougault V, Boulet LP. Airway dysfunction in swimmers. Br J Sports Med 2012 Published Online First: 12 January 2012 doi:10.1136/bjsports-2011-090821.

6. Sue-Chu M. Winter sports athletes: long-term effects of cold air exposure. Br J Sports Med 2012 Published Online First: 20 January 2012 doi:10.1136/ bjsports-2011-090822.

7. Rundell KW. Effect of air pollution on athlete health and performance. Br J Sports Med 2012 Published Online First: 20 January 2012 doi:10.1136/ bjsports-2011-090823.

8. Fitch KD. An overview of asthma and airway hyper-responsiveness in Olympic athletes. Br J Sports Med 2012 Published Online First: 8 January 2012 doi:10.1136/ bjsports-2011-090814.

9. Boulet LP. Cough and upper airway disorders in elite athletes: a critical review. Br J Sports Med 2012 Published Online First: 20 January 2012 doi:10.1136/ bjsports-2011-090812.
10. Bougault V, Turmel J, Boulet LP. Airway hyperresponsiveness in elite swimmers: is it a transient phenomenon? J Allergy Clin Immunol 2011;127:892-8.

11. Helenius I, Rytilä P, Sarna S, et al. Effect of continuing or finishing high-level sports on airway inflammation, bronchial hyperresponsiveness, and asthma: a 5-year prospective follow-up study of 42 highly trained swimmers. J Allergy Clin Immunol 2002;109:962-8

12. Leuppi JD, Kuhn M, Comminot C, et al. High prevalence of bronchial hyperresponsiveness and asthma in ice hockey players. Eur Respir J 1998;12 13-6.

13. Rundell KW. High levels of airborne ultrafine and fine particulate matter in indoor ice arenas. Inhal Toxicol 2003;15:237-50.

14. Anderson SD, Holzer K. Exercise-induced asthma: is it the right diagnosis in elite athletes? J Allergy Clin Immunol 2000;106:419-28.

15. Bougault V, Loubaki L, Joubert P, et al. Airway remodeling and inflammation in competitive swimmers training in indoor chlorinated swimming pools. J Allergy Clin Immunol 2012;129:351-8

16. Karjalainen EM, Laitinen A, Sue-Chu M, et al. Evidence of airway inflammation and remodeling in ski athletes with and without bronchial hyperresponsiveness to methacholine. Am J Respir Crit Care Med 2000;161:2086-91.

17. Anderson SD, Kippelen P. Airway injury as a mechanism for exercise-induced bronchoconstriction in elite athletes. J Allergy Clin Immunol 2008;122:225-35.

18. Gilbert IA, McFadden ER Jr. Airway cooling and rewarming. The second reaction sequence in exercise-induced asthma. J Clin Invest 1992:90:699-704.

19. Sue-Chu M, Brannan JD, Anderson SD, et al. Airway hyperresponsiveness to methacholine, adenosine 5-monophosphate, mannitol, eucapnic voluntary hyperpnoea and field exercise challenge in elite cross-country skiers. Br J Sports Med 2010;44:827-32

20. Bougault V, Turmel J, St-Laurent J, et al. Asthma, airway inflammation and epithelial damage in swimmers and cold-air athletes. Eur Respir J 2009;33:740-6.

21. Powers SK, Dodd S, Lawler J, et al. Incidence of exercise induced hypoxemia in elite endurance athletes at sea level. Eur J Appl Physiol Occup Physiol 1988;58 298-302.

22. Harms CA, McClaran SR, Nickele GA, et al. Exercise-induced arterial hypoxaemia in healthy young women. J Physiol (Lond) 1998;507:619-28.

23. Richards JC, McKenzie DC, Warburton DE, et al. Prevalence of exercise-induced arterial hypoxemia in healthy women. Med Sci Sports Exerc 2004;36:1514-21.

24. Powers SK, Lawler J, Dempsey JA, et al. Effects of incomplete pulmonary gas exchange on V02 max. J Appl Physiol 1989;66:2491-5.

25. Dempsey JA, Wagner PD. Exercise-induced arterial hypoxemia. J App/ Physiol 1999:87:1997-2006.

26. Eldridge MW, Braun RK, Yoneda KY, et al. Effects of altitude and exercise on pulmonary capillary integrity: evidence for subclinical high-altitude pulmonary edema. J Appl Physiol 2006;100:972-80.

27. Rundell KW, Spiering BA. Inspiratory stridor in elite athletes. Chest 2003:123:468-74

28. Wilson JJ, Theis SM, Wilson EM. Evaluation and management of vocal cord dysfunction in the athlete. Curr Sports Med Rep 2009:8:65-70.

29. Balkissoon R. Vocal cord dysfunction, gastroesophageal reflux disease, and nonallergic rhinitis. Clin Allergy Immunol 2007;19:411-26.

30. Heir T. Longitudinal variations in bronchial responsiveness in cross-country skiersand control subjects. Scand J Med Sci Sports 1994;4:134-9.

31. Rundell KW, Im J, Mayers LB, et al. Self-reported symptoms and exercise-induced asthma in the elite athlete. Med Sci Sports Exerc 2001;33:208-13.

32. Irwin RS, Baumann MH, Bolser DC, et al. Diagnosis and management of cough executive summary: ACCP evidence-based clinical practice guidelines. Chest 2006;129:1S-23S

33. Katelaris $\mathbf{C H}$, Carrozzi FM, Burke TV, et al. A springtime olympics demands special consideration for allergic athletes. J Allergy Clin Immunol 2000;106:260-6.

34. Bougault V, Turmel J, Boulet LP. Effect of intense swimming training on rhinitis in high-level competitive swimmers. Clin Exp Allergy 2010;40:1238-46.

35. Gleeson M, Pyne DB. Special feature for the Olympics: effects of exercise on the immune system: exercise effects on mucosal immunity. Immunol Cell Biol 2000:78:536-44.

36. Spence L, Brown WJ, Pyne DB, et al. Incidence, etiology, and symptomatology of upper respiratory illness in elite athletes. Med Sci Sports Exerc 2007;39:577-86.

37. Anderson SD, Daviskas E. The mechanism of exercise-induced asthma is. J Allergy Clin Immunol 2000;106:453-9.

38. Bolger C, Tufvesson E, Anderson SD, et al. The effect of inspired air conditions on exercise-induced bronchoconstriction and urinary CC16 levels in athletes. J Appl Physiol 2011;111:1059-65.

39. Mangla PK, Menon MP. Effect of nasal and oral breathing on exercise-induced asthma. Clin Allergy 1981;11:433-9.

40. Niinimaa V, Cole P, Mintz S, et al. The switching point from nasal to oronasa breathing. Respir Physiol 1980;42:61-71.

41. Schachter EN, Lach E, Lee M. The protective effect of a cold weather mask on exercised-induced asthma. Ann Allergy 1981;46:12-6.

42. Brenner AM, Weiser PC, Krogh LA, et al. Effectiveness of a portable face mask in attenuating exercise-induced asthma. JAMA 1980;244:2196-8. 
43. Nisar M, Spence DP, West D, et al. A mask to modify inspired air temperature and humidity and its effect on exercise induced asthma. Thorax 1992;47:446-50.

44. Eiken 0, Kaiser P, Holmér I, et al. Physiological effects of a mouth-borne heat exchanger during heavy exercise in a cold environment. Ergonomics 1989;32:645-53.

45. Beuther DA, Martin RJ. Efficacy of a heat exchanger mask in cold exercise-induced asthma. Chest 2006;129:1188-93.

46. Airtrim. http://www.airtrim.se/eng/default.asp (accessed 8 February 2012)

47. Millqvist $\mathbf{E}$, Bake $\mathrm{B}$, Bengtsson $\mathrm{U}$, et al. A breathing filter exchanging heat and moisture prevents asthma induced by cold air. Allergy 1995;50:225-8.

48. Lereim I. Sport at low temperatures: Prevention of cold injuries in snow sports, 2007. http://www.fis-ski.com./data/document/cold-lereim-long-article.pdf (accessed 2 February 2012).

49. Federation Internationale de Ski. International ski competition rules: book II, Cross country, 2008. http://www.fis-ski.com/data/document/icr cc 2008.pdf (accessed 2 February 2012).

50. International Biathlon Union (IBU). IBU event and competition rules, 2010. http://www.biathlonworld.com/media/files/downloads/Handbook2010_e cap3IBUEventandCompetitionRules.pdf (accessed 6 February 2012).

51. Barbee SJ, Thackara JW, Rinehart WE. Acute inhalation toxicology of nitrogen trichloride. Am Ind Hyg Assoc J 1983;44:145-6.

52. Carbonnelle $\mathbf{S}$, Francaux $\mathrm{M}$, Doyle I, et al. Changes in serum pneumoproteins caused by short-term exposures to nitrogen trichloride in indoor chlorinated swimming pools. Biomarkers 2002;7:464-78.

53. Carbonnelle S, Bernard A, Doyle IR, et al. Fractional exhaled NO and serum pneumoproteins after swimming in a chlorinated pool. Med Sci Sports Exerc 2008;40:1472-6.

54. Agence française de sécurité sanitaire de l'environnement et du travail (Afsset). Evaluation des risques sanitaires liés aux piscines - partie 1: piscines règlementées, 2010. http://www.anses.fr/ET/DocumentsET/10_06_ED_Piscines_reglementees Avis correction GLa p10.pdf (accessed 6 February 2012).

55. World Health Organization. International programme on chemical safety, environmental health criteria 216: disinfectants and disinfectant by-products, 2000. http://www.inchem.org/documents/ehc/ehc/ehc216.htm \#PartNumber:22000 (accessed 8 February 2012).

56. Pietropaoli AP, Frampton MW, Hyde RW, et al. Pulmonary function, diffusing capacity, and inflammation in healthy and asthmatic subjects exposed to ultrafine particles. Inhal Toxicol 2004;16 Suppl 1:59-72.

57. Broeckaert F, Arsalane K, Hermans C, et al. Lung epithelial damage at low concentrations of ambient ozone. Lancet 1999;353:900-1.

58. Folinsbee LJ. Human health effects of air pollution. Environ Health Perspect 1993;100:45-56

59. Bauer MA, Utell MJ, Morrow PE, et al. Inhalation of 0.30 ppm nitrogen dioxide potentiates exercise-induced bronchospasm in asthmatics. Am Rev Respir Dis 1986;134:1203-8.

60. Daigle CC, Chalupa DC, Gibb FR, et al. Ultrafine particle deposition in humans during rest and exercise. Inhal Toxicol 2003;15:539-52.

61. Levy JI, Lee K, Yanagisawa Y, et al. Determinants of nitrogen dioxide concentrations in indoor ice skating rinks. Am J Public Health 1998;88:1781-6.

62. Fitch K, Lu Y, Chen T, et al. Air quality and controls. In: Dapeng J, Ljungqvist A, Treodsson H, eds. The Health Legacy of the 2008 Beijing Olympic Games - successes and recommendations. Geneva, Switzerland: World Health Organization Press 2010:106-15

63. Hoffman MD, Clifford PS, Varkey B. Acute effects of ski waxing on pulmonary function. Med Sci Sports Exerc 1997:29:1379-82.

64. Oberdorster G, Gelein RM, Ferin J, et al. Association of particulate air pollution and acute mortality: involvement of ultrafine particles? Inhal Toxicol 1995;7:111-24.

65. Anderson SD, Kippelen P. Exercise-induced bronchoconstriction: pathogenesis. Curr Allergy Asthma Rep 2005;5:116-22.

66. Heir T, Aanestad G, Carlsen KH, et al. Respiratory tract infection and bronchial responsiveness in elite athletes and sedentary control subjects. Scand J Med Sci Sports 1995:5:94-9.

67. Reiff DB, Choudry NB, Pride NB, et al. The effect of prolonged submaximal warm-up exercise on exercise-induced asthma. Am Rev Respir Dis 1989:139:479-84.

68. de Bisschop C, Guenard H, Desnot P, et al. Reduction of exercise-induced asthma in children by short, repeated warm ups. Br J Sports Med 1999;33:100-4.

69. Morton AR, Hahn AG, Fitch KD. Continuous and intermittent running in the provocation of asthma. Ann Allergy 1982:48:123-9.
70. McKenzie DC, McLuckie SL, Stirling DR. The protective effects of continuous and interval exercise in athletes with exercise-induced asthma. Med Sci Sports Exerc 1994;26:951-6.

71. Riesenfeld EP, Sullivan MJ, Thompson-Figueroa JA, et al. Inhaled salmeterol and/ or fluticasone alters structure/function in a murine model of allergic airways disease. Respir Res 2010;11:22

72. Demnati R, Fraser R, Martin JG, et al. Effects of dexamethasone on functional and pathological changes in rat bronchi caused by high acute exposure to chlorine. Toxicol Sci 1998;45:242-6.

73. Sont JK, Willems LN, Bel EH, et al. Clinical control and histopathologic outcome of asthma when using airway hyperresponsiveness as an additional guide to long-term treatment. The AMPUL Study Group. Am J Respir Crit Care Med 1999;159: 1043-51

74. Jeffery PK, Godfrey RW, Adelroth E, et al. Effects of treatment on airway inflammation and thickening of basement membrane reticular collagen in asthma. A quantitative light and electron microscopic study. Am Rev Respir Dis 1992;145: 890-9.

75. Ward C, Pais M, Bish R, et al. Airway inflammation, basement membrane thickening and bronchial hyperresponsiveness in asthma. Thorax 2002;57:309-16.

76. Sue-Chu M, Karjalainen EM, Laitinen A, et al. Placebo-controlled study of inhaled budesonide on indices of airway inflammation in bronchoalveolar lavage fluid and bronchial biopsies in cross-country skiers. Respiration 2000;67:417-25.

77. Guilbert TW, Morgan WJ, Zeiger RS, et al. Long-term inhaled corticosteroids in preschool children at high risk for asthma. N Engl J Med 2006;354:1985-97.

78. Murray CS, Woodcock A, Langley SJ, et al. Secondary prevention of asthma by the use of Inhaled Fluticasone propionate in Wheezy INfants (IFWIN): double-blind, randomised, controlled study. Lancet 2006;368:754-62.

79. Rundell KW, Spiering BA, Baumann JM, et al. Effects of montelukast on airway narrowing from eucapnic voluntary hyperventilation and cold air exercise. Br J Sports Med 2005;39:232-6.

80. Helenius I, Lumme A, Ounap J, et al. No effect of montelukast on asthma-like symptoms in elite ice hockey players. Allergy 2004;59:39-44.

81. Rundell KW, Spiering BA, Baumann JM, et al. Bronchoconstriction provoked by exercise in a high-particulate-matter environment is attenuated by montelukast. Inhal Toxicol 2005;17:99-105.

82. Foucaud L, Bennasroune A, Klestadt D, et al. Oxidative stress induction by short time exposure to ozone on THP-1 cells. Toxicol In Vitro 2006;20:101-8.

83. Todokoro M, Mochizuki $\mathrm{H}$, Tokuyama K, et al. Effect of ozone exposure on intracellular glutathione redox state in cultured human airway epithelial cells. Inflammation 2004;28:105-14

84. Grievink L, Jansen SM, van't Veer P, et al. Acute effects of ozone on pulmonary function of cyclists receiving antioxidant supplements. Occup Environ Med 1998:55:13-7.

85. Grievink L, Zijlstra AG, Ke X, et al. Double-blind intervention trial on modulation of ozone effects on pulmonary function by antioxidant supplements. Am J Epidemiol 1999;149:306-14.

86. Gomes EC, Stone V, Florida-James G. Impact of heat and pollution on oxidative stress and CC16 secretion after 8 km run. Eur J Appl Physiol 2011;111:2089-97.

87. Neuman I, Nahum H, Ben-Amotz A. Reduction of exercise-induced asthma oxidative stress by lycopene, a natural antioxidant. Allergy 2000;55:1184-9.

88. Mickleborough TD, Murray RL, Ionescu AA, et al. Fish oil supplementation reduces severity of exercise-induced bronchoconstriction in elite athletes. Am J Respir Crit Care Med 2003;168:1181-9.

89. Baumann JM, Rundell KW, Evans TM, et al. Effects of cysteine donor supplementation on exercise-induced bronchoconstriction. Med Sci Sports Exerc 2005;37:1468-73.

90. Falk B, Gorev R, Zigel L, et al. Effect of lycopene supplementation on lung function after exercise in young athletes who complain of exercise-induced bronchoconstriction symptoms. Ann Allergy Asthma Immunol 2005;94:480-5.

91. Helenius IJ, Tikkanen HO, Sarna S, et al. Asthma and increased bronchial responsiveness in elite athletes: atopy and sport event as risk factors. J Allergy Clin Immunol 1998;101:646-52.

92. Mabalirajan U, Ahmad T, Leishangthem GD, et al. L-arginine reduces mitochondrial dysfunction and airway injury in murine allergic airway inflammation. Int Immunopharmacol 2010;10:1514-9.

93. Mabalirajan U, Ahmad T, Leishangthem GD, et al. Beneficial effects of high dose of L-arginine on airway hyperresponsiveness and airway inflammation in a murine model of asthma. J Allergy Clin Immunol 2010;125:626-35. 